\title{
Survival of Halobacteria Within Fluid Inclusions in Salt Crystals
}

\author{
By CYNTHIA F. NORTON ${ }^{1 *}$ AND WILLIAM D. GRANT ${ }^{2}$ \\ ${ }^{1}$ Department of Biology, University of Maine at Augusta, Augusta, Maine 04330, USA \\ ${ }^{2}$ Department of Microbiology, University of Leicester, Leicester LE1 7RH, UK
}

(Received 7 January 1988)

\begin{abstract}
When sodium chloride crystallizes in an evaporitic environment, living halobacteria are entrapped within the fluid inclusions which form as the crystals develop. Trapped cells have been observed in natural salts from a marine saltern and from Lake Magadi. Entrapment occurs under both neutral and alkaline conditions. Salt crystals have been grown under controlled conditions from solutions containing pure culture suspensions of halobacteria at densities comparable to those reported from natural evaporitic habitats. Crystals formed in solutions heavily loaded with bacterial cells contained more and larger inclusions than crystals formed from sterile solutions, and thus bacterial entrapment may affect the physical characteristics of the product. Representative strains of each major grouping within the Halobacteriaceae except the genus Halococcus exhibited entrapment and survival within salt crystals. Continued motility has been demonstrated for up to three weeks after entrapment. All strains tested to date retained viability for a minimum of six months. Non-motile and non-viable cells were also entrapped.
\end{abstract}

\section{INTRODUCTION}

The questions raised by the survival of 'red bacteria' in salt brines and on solar salt used for preserving fish, meat and hides have been of both historical and practical interest (BaasBecking, 1931). Harrison \& Kennedy (1922) demonstrated that the red discoloration of salted fish was due to the fact that red halobacteria remain viable in crude solar salt for periods of months after the salt has been harvested. Dussault (1958) established that bacterial survival in crude solar salt over periods of 20-60 d was improved by storage in warm, humid conditions, with salt samples even showing some increase in numbers under the most favourable storage conditions. The duration of survival has remained largely unsurveyed, although Bain et al. (1958) were able to recover viable 'pink bacteria' from solar salt samples that had been in storage for four years. The literature has tended to be non-specific about the actual relationship of the attendant bacterial flora to the crystalline salt. Some authors have employed the descriptive term 'contamination', thereby suggesting, perhaps unintentionally, a largely accidental and superficial relationship. The work reported here was undertaken in an effort to increase understanding of this relationship.

A key to understanding halobacterial survival in salt is found by examining the mineralogy of the host substance. Naturally deposited crystalline sodium chloride (halite) is a cubic mineral which, like many other minerals such as quartz, contains large numbers of fluid inclusions. The water content of natural rock salts, which is a significant factor in the mechanical behaviour of salt deposits (Urai et al., 1986) is usually in the range of $0.1-1.0 \%(w / w)$ (Roedder, 1984). The water content of freshly harvested solar salts is usually in the range of $2-6 \%(\mathrm{w} / \mathrm{w})$, in some cases up to $15 \%(\mathrm{w} / \mathrm{w})$ (Lefond, 1969). Fluid inclusions, readily observed under low power magnification or even in some instances with the unaided eye, may be described as negative cubes or oblongs with slightly rounded corners. They contain aqueous solutions and, in some cases, small gas bubbles; they range in size from less than $1 \mu \mathrm{m}$ in the longest dimension to several millimetres. Most, however, are in the micrometre size range. If the salt specimen in question has not been subjected to post-depositional modifications (extremes of heating and 
pressure, and/or solution and recrystallization) inclusion fluids may be considered to be unaltered samples of the evaporitic fluids from which the salt originally crystallized. Fluid inclusions in halite are the subject of a significant body of work in the geological literature, recently reviewed by Roedder (1984).

To determine the extent of bacterial entrapment in fluid inclusions, and its possible role in promoting halobacterial survival in salt, we have employed a simple model in which pure cultures of halobacteria were added to saturated salt solutions, in numbers that approximated the values from $10^{6}$ to $10^{7}$ bacterial cells $\mathrm{ml}^{-1}$ reported for natural salt lakes and saltern fluids (Nixon, 1970; Nissenbaum, 1975; Larsen, 1977; Post, 1977). These solutions were then allowed to form crystals. Crystals were also grown from hypersaline water samples collected on site, containing a mixed flora. Examination of harvested crystals readily showed us that bacteria of all types were being incorporated directly into the native structure of the crystals as they formed.

This paper demonstrates that the ability to survive in association with crystalline salt is a widely distributed property, that it is probably characteristic of all halobacteria, and that entrapment plays a role in survival. We also present evidence for continued viability of halobacteria within the primary fluid inclusions formed in salt crystals.

\section{METHODS}

Organisms and media. The bacterial strains used (listed in Table 1) comprised representatives of the genera Halobacterium, Haloferax and Haloarcula (Torreblanca et al., 1986), Halococcus, Natronobacterium, and Natronococcus, plus a number of unclassified halobacteria growing at neutral $\mathrm{pH}$ (neutrophiles). The latter have been isolated from solar salts and saltern fluids (sources as indicated). Neutrophilic strain BH1, which has been extensively used in these studies, is a motile, gas-vacuolate flattened rod isolated in 1985 from solar salt produced on the island of Bonaire, Netherlands Antilles.

Neutrophiles, with the exceptions noted, were maintained on a modification of the halophile medium of Payne et al. (1960). This medium (HM) was prepared in two parts which were mixed after autoclaving. Part I contained yeast extract, $10.0 \mathrm{~g}$; vitamin-free Casamino acids, $7.5 \mathrm{~g} ; \mathrm{KCl}, 2.0 \mathrm{~g}$; trisodium citrate, $3.0 \mathrm{~g} ; \mathrm{MnCl}_{2} .4 \mathrm{H}_{2} \mathrm{O}$ stock solution $\left(0.36 \mathrm{~g} \mathrm{l}^{-1}\right), 1 \mathrm{ml}$; and $\mathrm{FeSO}_{4} .7 \mathrm{H}_{2} \mathrm{O}$ stock solution $\left(50.0 \mathrm{~g} \mathrm{l}^{-1}\right), 1 \mathrm{ml}$; distilled water was added to a final volume of $500 \mathrm{ml}$. Part II contained $200 \mathrm{~g} \mathrm{NaCl}$ and $20 \mathrm{~g} \mathrm{MgSO}_{4} .7 \mathrm{H}_{2} \mathrm{O}$ in distilled water to a final volume of $500 \mathrm{ml}$. The $\mathrm{pH}$ of part I was adjusted to 7.5 and agar $\left(18 \mathrm{~g} \mathrm{l}^{-1}\right)$ added if required before autoclaving. Larsen's medium 1 (Larsen, 1981), made with $25 \%$ (w/v) analytical grade $\mathrm{NaCl}$, was used for bulk growth of 'Halobacterium halobium' CCM 2090; HM, modified to contain $35 \% \mathrm{NaCl}$ (a saturated solution), was used for bulk growth of strain BH1. Alkaliphilic halophiles were grown in the medium of Tindall et al. (1980), a low magnesium medium which contains $\mathrm{NaCl}(20 \% \mathrm{w} / \mathrm{v})$ and anhydrous $\mathrm{Na}_{2} \mathrm{CO}_{3}(1 \cdot 8 \% \mathrm{w} / \mathrm{v})$ producing an initial $\mathrm{pH}$ of $10 \cdot 0$. All organisms were maintained on solid media. For crystallization studies, they were transferred to liquid media and grown to stationary phase at $37^{\circ} \mathrm{C}$ in an illuminated Gallenkamp orbital incubator at 150 r.p.m.

Preparation of crystals. Stationary phase cultures $(10 \mathrm{ml}$ volumes) were spun down. Neutrophilic strains were washed once in sterile $20 \%(\mathrm{w} / \mathrm{v}) \mathrm{NaCl}$ solution, then resuspended in sterile saturated $\mathrm{NaCl}$ solution to the desired cell density, determined by direct microscopic counts. Alkaliphilic strains were washed and resuspended in a sterile solution saturated with both $\mathrm{NaCl}$ and $\mathrm{Na}_{2} \mathrm{CO}_{3}$. A $20 \mathrm{ml}$ sample of the cell suspension was put in a sterile $75 \mathrm{~mm}$ glass Petri dish and placed in an incubator at $37^{\circ} \mathrm{C}$ without shaking or other disturbance. Crystallization was usually initiated $12-18 \mathrm{~h}$ later. Individual well-formed crystals, 2-4 mm in each dimension, were harvested aseptically and stored in screw-capped glass vials at room temperature in the dark. Direct observations of the fluid inclusions and their contents were made with a Leitz Ortholux microscope using phase-contrast optics. For scanning electron microscopy, crystals were cleaved with a single-sided razor blade, air-dried, mounted, given a $5 \mathrm{~nm}$ gold coating, then viewed using an ISI-DS 130 scanning electron microscope.

\section{RESULTS}

\section{Enclosure within fluid inclusions}

Recognizable bacterial cells were observed within inclusions in several natural solar salt samples collected on site at a marine saltern in Puerto Rico and at Lake Magadi, an alkaline lake in Kenya.

A total of 40 strains of halobacteria were examined as pure cultures for their ability to be incorporated into salt crystals under controlled conditions, using the crystal growth method described above. All the strains shown in Table 1, except for Halococcus morrhuae strains 
Table 1. Origins of strains

$\begin{array}{lll}\text { Genus } & \text { Species or strain } & \text { Source and number* } \\ \text { Halobacterium } & \text { 'Hb. salinarium' } & \text { NCMB 764, NCMB 786, CCM 2148 } \\ & \text { 'Hb. halobium' } & \text { CCM 2090 } \\ & \text { 'Hb. cutirubrum' } & \text { NCMB 2088 } \\ & \text { 'Hb. saccharovorum } & \text { NCMB 2081 } \\ & \text { 'Hb. simoncinii' } & \text { NCMB 773 } \\ & \text { 'Hb. caglieri' } & \text { NCMB 748 } \\ \text { 'Ha. maris-mortui' } & \text { MG1 } \\ \text { Haloarcula } & \text { Ha. vallismortis } & \text { ATCC 29715 } \\ & \text { Ha. trapanicum } & \text { NCMB 784, NRC 34021 } \\ & \text { Hf. volcanii } & \text { NCMB 2012 } \\ \text { Haloferax } & \text { Hf. mediterranei } & \text { CCM 3361 } \\ & \text { Hc. morrhuae } & \text { NCMB 749, NCMB 757, NCMB 761, NCMB 776, } \\ \text { Halococcus } & & \text { NCMB 787, CCM 2526 } \\ & & \text { NCMB 2191, DSM 2160 } \\ \text { Natronobacterium } & \text { Nb. pharaonis } & \text { NCMB 2189 } \\ & \text { Nb. gregoryi } & \text { NCMB 2190 } \\ \text { Natronococcus } & \text { Nc. } \text { occultus } & \text { NCMB 2192 } \\ \text { Unidentified strains } & & \\ \text { BH1, BH3, BH5 } & & \\ \text { PR10, PR18, PR19, PR21, PR22, PR23 } & \text { Solar salt, Bonaire } \\ \text { SK3, SK4 } & & \text { Mud, abandoned saltern, St Kitts } \\ \text { T1 } & & \text { Saltern fluid, Tavira } \\ \text { O1 } & & \text { Saltern fluid, Olmao } \\ & & \end{array}$

* CCM, Czechoslovakian Collection of Micro-organisms, (Brno, Czechoslovakia); DSM, Deutsche Sammlung von Mikro-organismen (Munich, FRG); NCMB, National Collection of Marine Bacteria (Aberdeen, UK); ATCC, American Type Culture Collection (Maryland, USA); NRC, National Research Council of Canada (Ottawa, Canada).

NCMB 757 and NCMB 787, could be seen by light microscopic examination to be incorporated into fluid inclusions within salt crystals (Fig. 1). Because of the refractivity of the fluid/salt inclusion boundaries, it was only possible to photograph and estimate the cell numbers in the smaller fluid inclusions and those near the outer surfaces of a crystal. Halite has a refractive index of 1.5443 , relatively close to the values for glass and immersion oil, but significantly higher than the values for water and aqueous solutions. It is therefore possible to apply standard immersion oil directly to the surface of a crystal to permit the use of high-magnification lenses if desired.

Cell density in the incorporated fluid varied widely from crystal to crystal in a batch and even between adjacent inclusions in the same crystal, with the innermost inclusions always containing the most densely packed fluid. However, the density of cells in the trapped fluid was always equal to and usually much higher than that in the crystallizing mixture. In many instances the fluid was visibly coloured with the packed cells. Individual crystals were cleaved vertically along $\{100\}$ planes as illustrated in Fig. 4(a), exposing individual fluid inclusions. The $\{100\}$ plane is a natural vertical cleavage plane found in crystals with a cubic symmetry such as halite. Cells were observed by scanning electron microscopy both within the inclusions and lying in sheets on the exposed cleavage face of the salt (Fig. 2).

\section{Indications of intracrystalline viability}

Continued microscopic observations of entrapped bacteria over the period of three months post-harvest showed that many retained their typical morphology for this period, despite the presumed starvation conditions experienced within the fluid inclusions. However, many of the rod-shaped forms rounded up within two to three weeks post-harvest, as they would typically do 

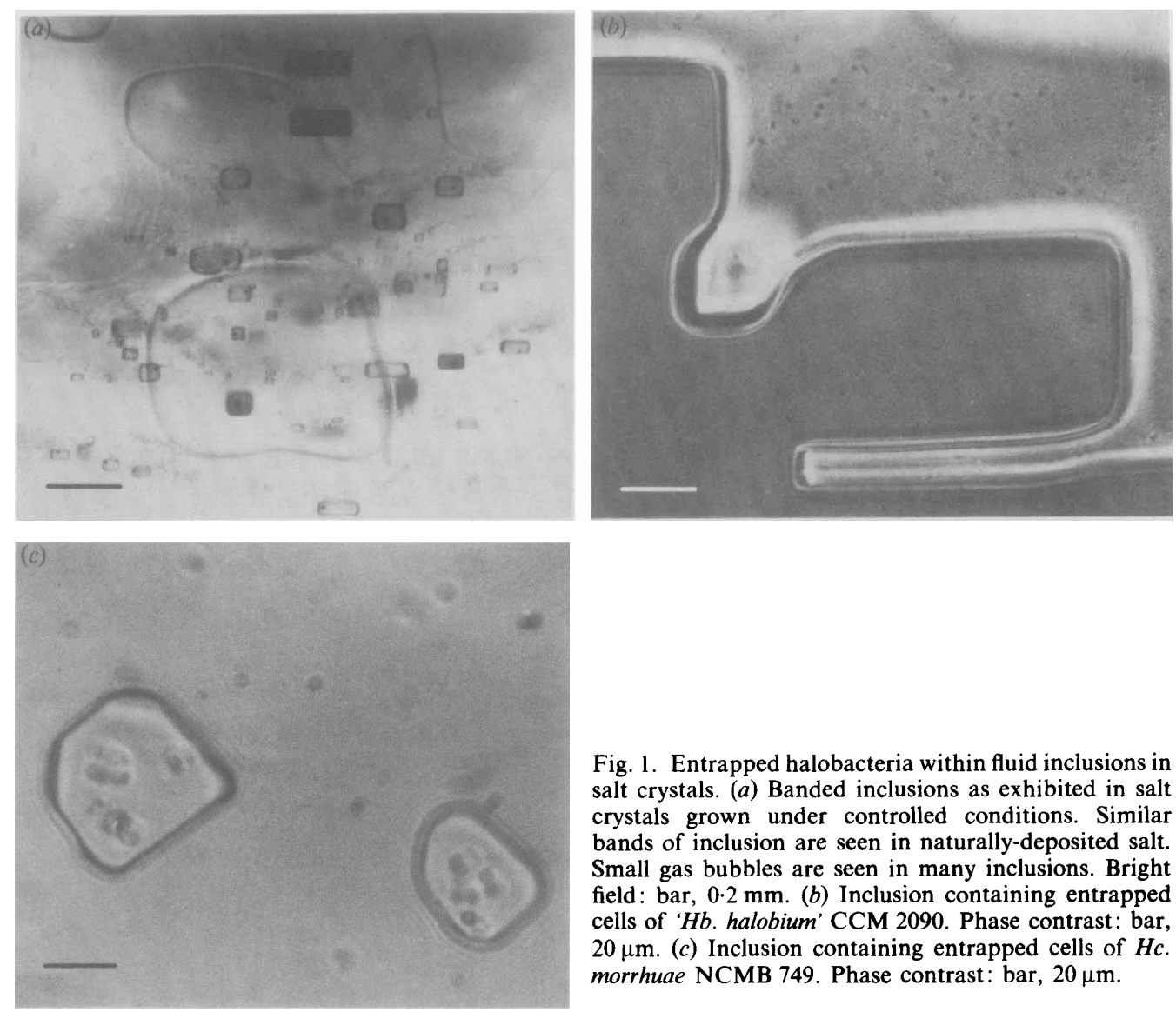

Fig. 1. Entrapped halobacteria within fluid inclusions in salt crystals. (a) Banded inclusions as exhibited in salt crystals grown under controlled conditions. Similar bands of inclusion are seen in naturally-deposited salt. Small gas bubbles are seen in many inclusions. Bright field: bar, $0.2 \mathrm{~mm}$. (b) Inclusion containing entrapped cells of 'Hb. halobium' CCM 2090. Phase contrast: bar, $20 \mu \mathrm{m}$. (c) Inclusion containing entrapped cells of $\mathbf{H c}$. morrhuae NCMB 749. Phase contrast: bar, $20 \mu \mathrm{m}$.

in a stationary phase or starved state. Otherwise, cells retained their normal density, did not clump or aggregate, and in general showed no obvious signs of lysis or gross loss of cytoplasmic contents.

Successful direct observations of continued intracrystalline motility were made on three rodshaped strains, BH1, 'Hb. halobium' CCM 2090, and Natronobacterium gregoryi NCMB 2189. Motility of some cells persisted for at least three weeks. However, the direct microscopic assessment of motility in the numerous flattened, pleomorphic or disc-shaped strains included in this study can be ambiguous under the best of conditions. Thus it was not possible to either confirm or exclude intracrystalline motility in most cases.

On several occasions, densely packed cells within inclusions exhibited unusual, regular packing patterns (Fig. 3). In the case of the pattern shown in Fig. 3(a), the packed cells later dispersed into other interconnected areas of the large branched inclusion shown. It is possible that in some strains a type of migratory behaviour may be present.

\section{Survival within fluid inclusions}

To determine the viability of crystal-associated bacteria, an individual salt crystal containing cells of a test strain was placed in a $10 \mathrm{ml}$ vial of halophile broth and incubated with shaking. Each strain that was positive for growth was streaked on a fresh plate and checked for purity. All strains listed in Table 1, except for the Hc. morrhuae strains, grew out within 5-10 d, demonstrating their ability to survive in association with salt crystals in storage. In order to determine further whether the viable cells in the system were limited to those on the outer 

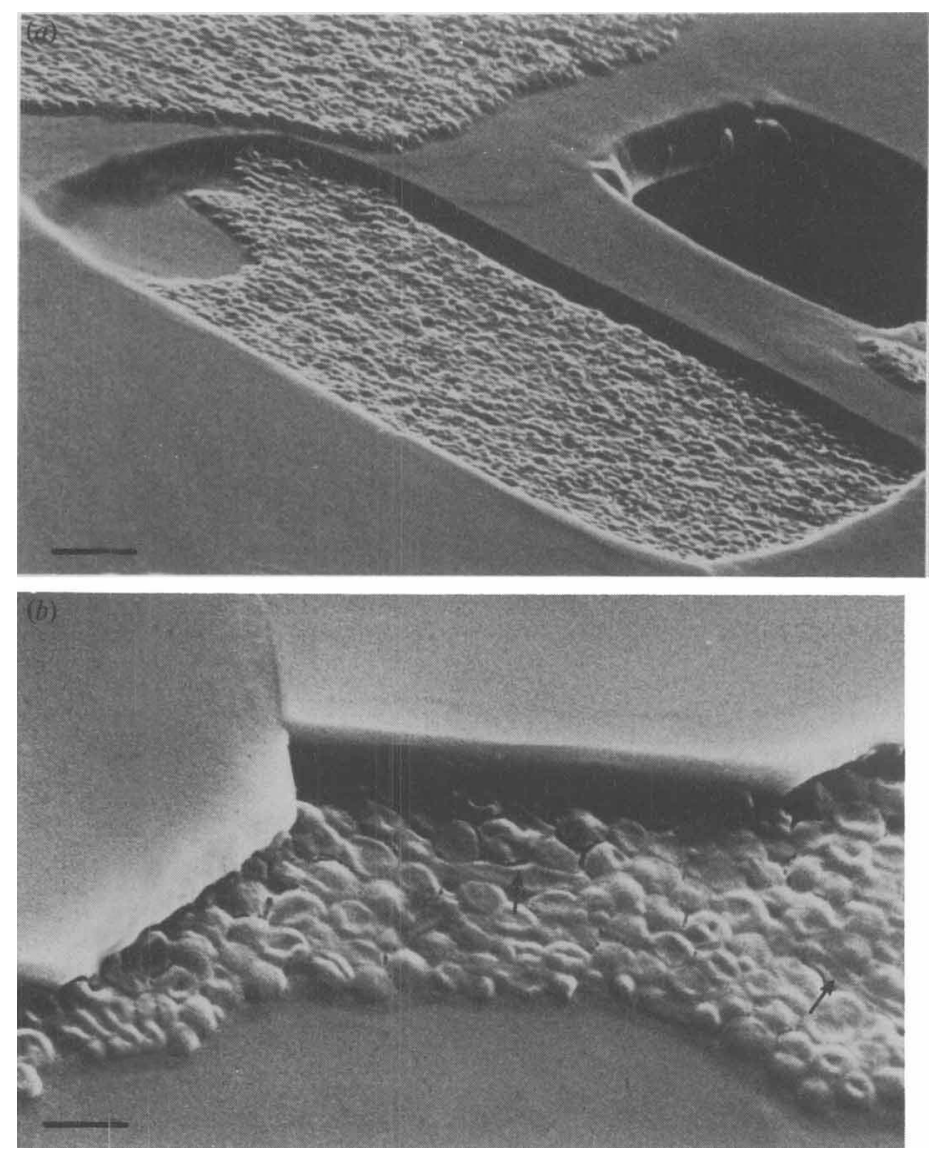

Fig. 2. Scanning electron microscopy of entrapped halobacteria. (a) Cells of ' Hb. halobium' CCM 2090 clustered in the cavity of a fluid inclusion exposed by cleavage. Left hand inclusion contains cells; right hand inclusion branches into underlying inclusion. Bar, $4.35 \mu \mathrm{m}$. (b) Cells released from ruptured inclusion. Note that the cells are mostly small and rounded but some longer rods are seen (arrow). Collapsed gas vesicles cause a dimpled effect. Bar. 1.65 $\mu \mathrm{m}$.

Table 2. Survival after six months entrapment within salt crystals: strains tested to date

$\begin{array}{ll}\text { Hb. salinarium } & \text { NCMB 764, NCMB 786, CCM } 2148 \\ \text { 'Hb. halobium' } & \text { CCM 2090 } \\ \text { 'Hb. simoncinii' } & \text { NCMB 773 } \\ \text { 'Hb. caglieri' } & \text { NCMB 748 } \\ \text { Hb. saccharovorum } & \text { NCMB 2081 } \\ \text { 'Ha. maris-mortui' } & \text { MG1 } \\ \text { Ha. vallismortis } & \text { ATCC 29715 } \\ \text { Ha. trapanicum } & \text { NCMB 784 } \\ \text { Hf. volcanii } & \text { NCMB 2012 } \\ \text { BH1 } & \\ \text { SK3 } & \end{array}$

surfaces of the crystals or could include those trapped within the fluid inclusions, the surface flora was eliminated by using a simple surface-sterilization procedure of immersing the crystals in absolute ethanol for $24 \mathrm{~h}$ prior to placing them in the media. The crystals that were used were specimens that had been harvested and held in storage for six months. Outgrowth from surfacesterilized crystals was compared with that from aseptically harvested but unsterilized crystals from the same batch (Table 2). In each case, outgrowth occurred from both; however, in most 

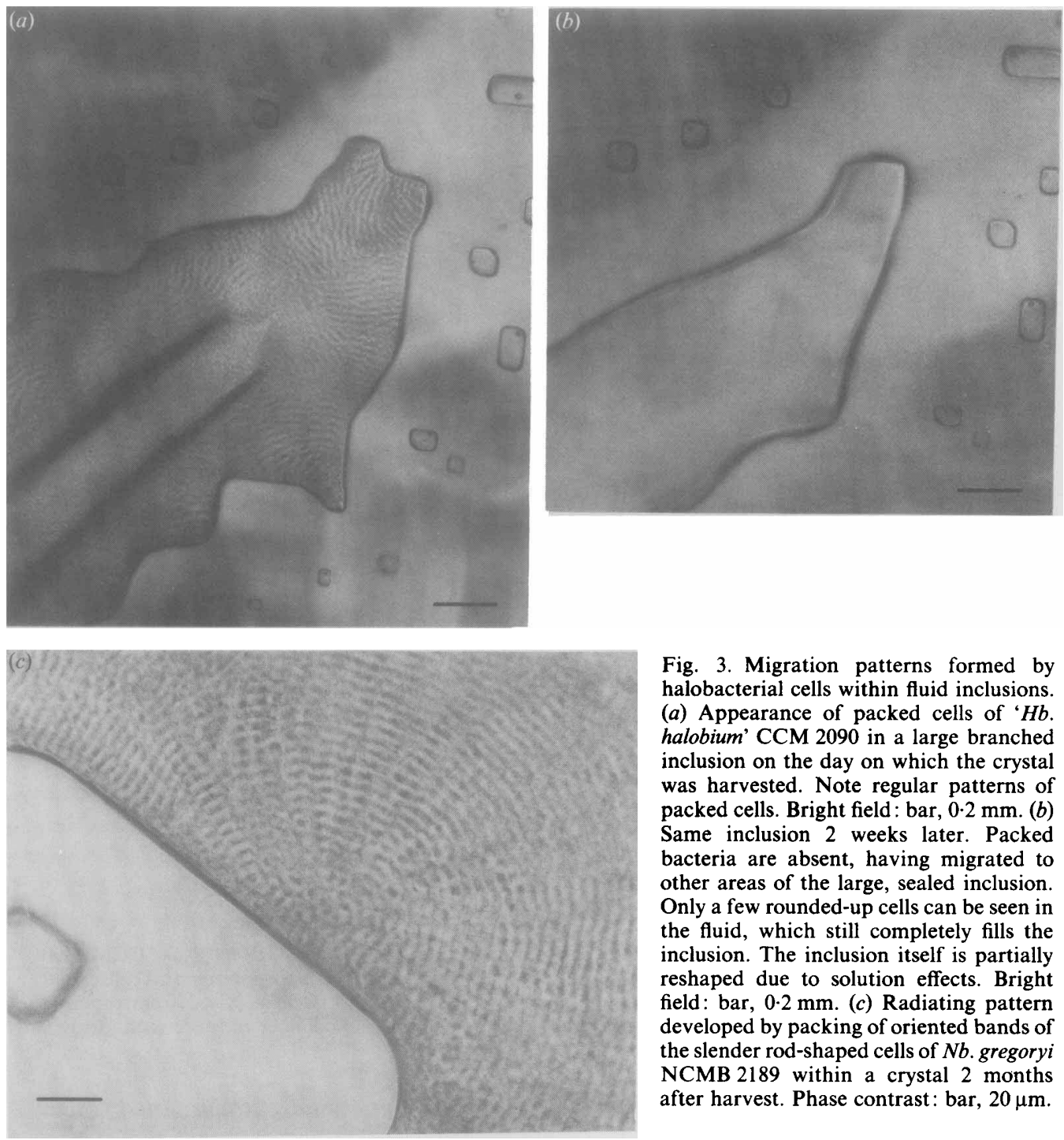

Fig. 3. Migration patterns formed by halobacterial cells within fluid inclusions. (a) Appearance of packed cells of ' $\mathrm{Hb}$. halobium' CCM 2090 in a large branched inclusion on the day on which the crystal was harvested. Note regular patterns of packed cells. Bright field: bar, $0.2 \mathrm{~mm}$. (b) Same inclusion 2 weeks later. Packed bacteria are absent, having migrated to other areas of the large, sealed inclusion. Only a few rounded-up cells can be seen in the fluid, which still completely fills the inclusion. The inclusion itself is partially reshaped due to solution effects. Bright field: bar, $0.2 \mathrm{~mm}$. (c) Radiating pattern developed by packing of oriented bands of the slender rod-shaped cells of $N b$. gregoryi NCMB 2189 within a crystal 2 months after harvest. Phase contrast: bar, $20 \mu \mathrm{m}$.

cases, growth was more rapid from non-sterilized crystals, indicating that the surface flora were making a significant additional contribution to the outgrowth potential of the salt specimen.

\section{Incorporation of natural mixed populations from soda lake samples}

In order to demonstrate that the inclusion survival effect might operate under more natural circumstances, crystals were grown from natural evaporitic fluids containing their original mixed flora. Five three-month old, highly alkaline hypersaline water samples collected from sites on Lake Magadi, Kenya, were used. The samples, when initially examined microscopically, were seen to contain dense populations of highly pleomorphic bacteria. When streaked on alkaliphile media, each sample contained a mixture of at least three, and in some instances more, distinct colonial morphologies. Samples $(20 \mathrm{ml})$ from each were allowed to crystallize under our conditions. The harvested crystals were examined microscopically, and bacteria were observed trapped in fluid inclusions. Specimen crystals were surface-disinfected and placed in 
(a)
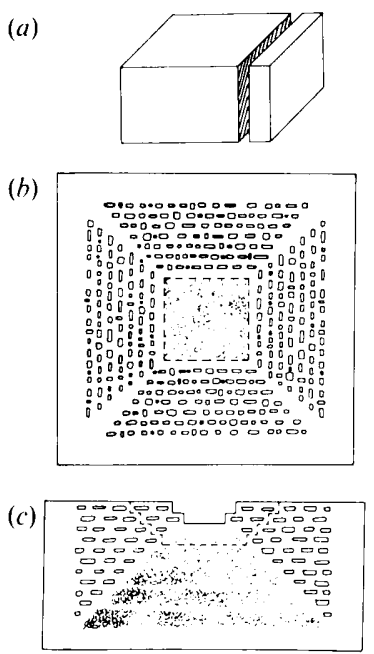

Fig. 4. Schematic illustrations of the features of a typical salt crystal containing entrapped halobacteria. (a) Orientation of the $\{100\}$ plane of vertical crystal cleavage used to reveal inclusions for scanning electron microscope examination. (b) Appearance of crystal from above. The central area (stippled) is a zone of core inclusions which contain packed bacterial cells in a thick suspension. Radiating from the core are parallel rows of bacteria-containing banded inclusions, separated on the diagonals by zones of almost inclusion-free halite. The peripheral zone of the crystal is also relatively free of inclusions. Viewed without magnification the core inclusion area will often appear reddish, the banded zones cloudy or translucent, and the inclusion-free zones transparent. (c) The crystal structure as seen from the side, with a crystal cleavage vertically through the centre. The dotted line and top depression suggest two possible stages in the filling of the hopper crystal once it sinks.

alkaliphile broth to permit outgrowth. In each case, a mixed population arose, of a diversity similar to that previously recovered from the parent water sample.

\section{Effects of bacterial incorporation on salt crystal structure}

In accordance with the general pattern for naturally forming evaporitic salt (Roedder, 1984) salt crystals under these conditions developed primarily as so-called hopper crystals. The crystal, first seen as a microscopic flat plate of halite floating on the surface, gradually enlarges and thickens. As the crystal floats lower in the fluid, growth continues at and below the surface on the sides and bottom, with banded inclusions being trapped in parallel rows between layers of halite. This growth pattern, however, gives rise to a concave top surface, a hopper. Eventually surface tension no longer supports the weight of the crystal and it sinks. The hopper depression then rapidly fills with halite, in an irregular manner, entrapping one or more large, central core inclusions (Fig. 4). Bacteria are trapped in all types of inclusions, but in the highest concentrations at the core.

Fluid inclusions are formed whether bacteria are present or not. However, crystals formed in solutions containing bacteria generally contain many more and larger fluid inclusions than controls formed in sterile salt solutions. As a result, the total amount of trapped fluid is greater. They also characteristically have very large and highly ramified core and lateral inclusion systems, the contents of which are often visibly coloured due to the carotenoid pigments of the trapped bacteria. Control crystals usually lack such macroscopic structural discontinuities.

\section{Effects of bacterial incorporation on the rate of crystal growth}

A preliminary comparison was made of the rate of crystallization in saturated $\mathrm{NaCl}$ solutions containing halobacteria with that in otherwise identical sterile brines. Characteristically, crystallization began $24-28 \mathrm{~h}$ earlier in all samples containing bacteria than in sterile controls. 
This result is not unexpected, considering the well-understood phenomenon whereby foreign particles act as seeds or nuclei to promote crystal formation in saturated solutions. The effect of varying the numbers of bacteria present was evaluated by adding bacteria to final concentrations of approximately $4 \times 10^{6}, 4 \times 10^{7}$, and $4 \times 10^{8}$ cells $\mathrm{ml}^{-1}$. No significant differences were found in the time taken to initiate crystallization, or in the numbers of crystals formed. After 5-7 d, the total crystal yields were harvested and their wet and superficially dry $\left(7 \mathrm{~d}\right.$ at $200{ }^{\circ} \mathrm{C}$ ) weights were determined. Neither value was significantly affected by variation in the microbial load of the crystallizing liquor within the range studied.

The effects of viable cells were compared with those of non-viable cells. Cells of ' $\mathrm{Hb}$. halobium' CCM 2090 or of strain $\mathrm{BH} 1$ were added to sterile saturated $\mathrm{NaCl}$ solution to a final density of about $2 \times 10^{8}$ cells $\mathrm{ml}^{-1}$. The suspension was divided in two equal parts. To one sample was added $40 \%(\mathrm{v} / \mathrm{v})$ formaldehyde solution to yield a final concentration of $1 \%$; to the other was added an equivalent volume of sterile distilled water to equalize the dilution factor. No significant difference was noted in crystallization kinetics between solutions with live and dead cells.

\section{DISCUSSION}

The physicochemical stresses imposed on, and successfully tolerated by, the extreme halophiles in the salterns, lakes and pools they inhabit are well understood. However, it is perhaps less well understood that these micro-organisms face even more severe challenges in that most, perhaps all, of their natural aquatic habitats experience major fluctuations in water level. Some may periodically or permanently dry up, as evidenced by the ample salt beds that record this wholesale form of habitat destruction. It is perhaps not surprising that a habitatspecific mechanism exists that permits halobacteria to survive a temporary loss of their macrohabitat by becoming enclosed within a highly stable microhabitat, the fluid inclusion.

The work reported here documents the intracrystalline entrapment and survival of a diverse group of halobacteria over a short period. We have demonstrated the entrapment of pure cultures from synthetic fluids, and of mixed populations from natural saline waters. We have demonstrated survival for six months and will be extending the time to look for any outer limits on survival. The effects in question operate in both neutral and alkaline hypersaline solutions.

It is noteworthy that halobacteria are included even if they are non-motile or non-viable. A perhaps related observation is that visible deposits of cells also accumulate from an initially homogeneous suspension, in the immediate areas around and under growing crystals, whether the cells in question are viable or not. A physicochemical mechanism such as these observations suggest could operate in a saltern to entrap and preserve other types of organisms, such as moderate halophiles, that might already have become physiologically inactive by the time the saturation point was reached. The physical effects on the salt crystals formed in a solution with a large bacterial load will be investigated further.

It would be premature to speculate on the physiological state of the trapped halobacteria. In an illuminated environment, a continued energy supply might be obtained through lightmediated ATP synthesis under anaerobic conditions, which is possible for those strains containing bacteriorhodopsin (Danon \& Stoeckenius, 1974). Although organic nutrients might quite rapidly be exhausted, the interior of a fluid inclusion would, if the salt were not buried, receive some light, and oxygen would be excluded. These are the conditions described by Brock \& Petersen (1976) as most favourable for the survival of starved halobacteria. Starvation itself is relatively well-tolerated by halobacteria, and does not prevent them from maintaining high internal $\mathrm{K}^{+}$concentrations for short periods (Gochnauer \& Kushner, 1969, 1971).

These observations establish a context within which to consider the possibility of very-longterm survival of halobacteria in salt. We are investigating the use of encrystallization to preserve stock cultures of halobacteria. It seems possible that the stable microenvironment of a fluid inclusion deep within a salt crystal or deposit could provide suitable conditions to maintain bacterial viability for a prolonged period. 
The work reported here was done while C.F.N. was a visiting professor at the University of Leicester. C.F.N. wishes to thank George McTurk for technical assistance with the scanning electron microscopy, Gary Pinch for the illustrations, the Department of Microbiology at the University of Leicester for their hospitality and the University of Maine for sabbatical support.

\section{REFERENCES}

BAAs-BeCKING, L. G. M. (1931). Historical notes on salt and salt-manufacture. Scientific Monthly 32, 434-446.

Bain, N., Hodgkiss, W. \& Shewan, J. M. (1958). The bacteriology of salt used in fish curing. In The Microbiology of Fish and Meat Curing Brines (Proceedings of the 2nd International Symposium on Food Microbiology), pp. 1-11. Edited by B. P. Eddy. London: H. M. Stationery Office.

Brock, T. D. \& Petersen, S. (1976). Some effects of light on the viability of rhodopsin-containing halobacteria. Archives of Microbiology 107, 199-200.

Danon, A. \& Stoeckenius, W. (1974). Photophosphorylation in Halobacterium halobium. Proceedings of the National Academy of Sciences of the United States of America 71, 1234-1238.

Dussault, H. P. (1958). The fate of red halophilic bacteria in solar salt during storage. In The Microbiology of Fish and Meat Curing Brines (Proceedings of the 2nd International Symposium on Food Microbiology), pp. 13-19. Edited by B. P. Eddy. London: H. M. Stationery Office.

GochNAUER, M. B. \& KUSHNER, D. J. (1969). Growth and nutrition of extremely halophilic bacteria. Canadian Journal of Microbiology 15, 1157-1165.

GoChNauer, M. B. \& Kushner, D. J. (1971). Potassium binding, growth and survival of an extremely halophilic bacterium. Canadian Journal of Microbiology 17, 17-23.

HARRISON, F. C. \& KenNedY, M. E. (1922). XVI. The red discoloration of cured codfish. Transactions of the Royal Society of Canada 16, 101-152.

LARSEN, H. (1977). Ecology of hypersaline environments. In Hypersaline Brines and Evaporitic Environments. Developments in Sedimentology, vol. 28, pp. 23-39. Edited by A. Nissenbaum. Amsterdam: Elsevier.
LARSEN, H. (1981). The family Halobacteriaceae. In The Prokaryotes. A Handbook on Habitat, Isolation, and Identification of Bacteria, vol. I, pp. 985-994. Edited by M. P. Starr, H. Stolp, H. G. Trüper, A. Balows \& H. G. Schlegel. Berlin, Heidelberg \& New York: Springer.

LEFOND, S. J. (1969). Handbook of World Salt Resources. New York: Plenum Press.

Nissenbaum, A. (1975). The microbiology and biogeochemistry of the Dead Sea. Microbial Ecology 2, 139161.

NIXON, S. (1970). Characteristics of some hypersaline ecosystems. PhD thesis, University of North Carolina, Chapel Hill, North Carolina.

Payne, S. I., Sehgal, S. N. \& Gibbons, N. G. (1960). Immersion refractometry of some halophilic bacteria. Canadian Journal of Microbiology 6, 9-15.

Post, F. J. (1977). The microbial ecology of the Great Salt Lake. Microbial Ecology 3, 143-165.

ROEDDER, E. (1984). The fluids in salt. American Mineralogist 69, 413-439.

Tindall, B. J., Mills, A. A. \& Grant, W. D. (1980). An alkalophilic red halophilic bacterium with a low magnesium requirement from a Kenyan soda lake. Journal of General Microbiology 116, 257-260.

TorreblanCa, M., Rodriguez-Valera, F., Juez, G., Ventosa, A., Kamekura, M. \& Kates, M. (1986). Classification of non-alkaliphilic halobacteria based on numerical taxonomy and polar lipid composition, and description of Haloarcula gen. nov. and Haloferax gen. nov. Systematic and Applied Microbiology 8, 89-99.

Urai, J. L., Spiers, C. J., Zwart, H. J. \& Lister, G. S. (1986). Weakening of rock salt by water during longterm creep. Nature, London 324, 584-557. 